\title{
Additive manufactured polymeric 3D scaffolds with tailored surface topography influence mesenchymal stromal cells activity
}

Citation for published version (APA):

Neves, S. C., Mota, C., Longoni, A., Barrias, C. C., Granja, P. L., \& Moroni, L. (2016). Additive manufactured polymeric 3D scaffolds with tailored surface topography influence mesenchymal stromal cells activity. Biofabrication, 8(2), [025012]. https://doi.org/10.1088/1758-5090/8/2/025012

Document status and date:

Published: 01/06/2016

DOI:

10.1088/1758-5090/8/2/025012

Document Version:

Publisher's PDF, also known as Version of record

Document license:

Taverne

Please check the document version of this publication:

- A submitted manuscript is the version of the article upon submission and before peer-review. There can be important differences between the submitted version and the official published version of record.

People interested in the research are advised to contact the author for the final version of the publication, or visit the DOI to the publisher's website.

- The final author version and the galley proof are versions of the publication after peer review.

- The final published version features the final layout of the paper including the volume, issue and page numbers.

Link to publication

\footnotetext{
General rights rights.

- You may freely distribute the URL identifying the publication in the public portal. please follow below link for the End User Agreement:

www.umlib.nl/taverne-license

Take down policy

If you believe that this document breaches copyright please contact us at:

repository@maastrichtuniversity.nl

providing details and we will investigate your claim.
}

Copyright and moral rights for the publications made accessible in the public portal are retained by the authors and/or other copyright owners and it is a condition of accessing publications that users recognise and abide by the legal requirements associated with these

- Users may download and print one copy of any publication from the public portal for the purpose of private study or research.

- You may not further distribute the material or use it for any profit-making activity or commercial gain

If the publication is distributed under the terms of Article $25 \mathrm{fa}$ of the Dutch Copyright Act, indicated by the "Taverne" license above, 
PAPER

\section{Additive manufactured polymeric 3D scaffolds with tailored surface topography influence mesenchymal stromal cells activity}

To cite this article: Sara C Neves et al 2016 Biofabrication 8025012

View the article online for updates and enhancements.

\section{Related content}

Toward mimicking the bone structure: design of novel hierarchical scaffolds with a tailored radial porosity gradient Andrea Di Luca, Alessia Longoni, Giuseppe Criscenti et al.

- Surface energy and stiffness discrete gradients in additive manufactured scaffolds for osteochondral regeneration Andrea Di Luca, Alessia Longoni, Giuseppe Criscenti et al.

- Surface modification of electrospun fibre meshes by oxygen plasma for bone regeneration

A Nandakumar, Z Tahmasebi Birgani, D Santos et al.

\section{Recent citations \\ - Dario Puppi and Federica Chiellini \\ - Multiscale porosity in mesoporous bioglass 3D-printed scaffolds for bone regeneration M. Natividad Gómez-Cerezo et al \\ Construction of a hierarchical micro \& nanoporous surface for loading genistein on the composite of \\ polvetheretherketone/tantalum pentoxide possessing antibacterial activity and accelerated osteointegration Shiqi Mei et al}

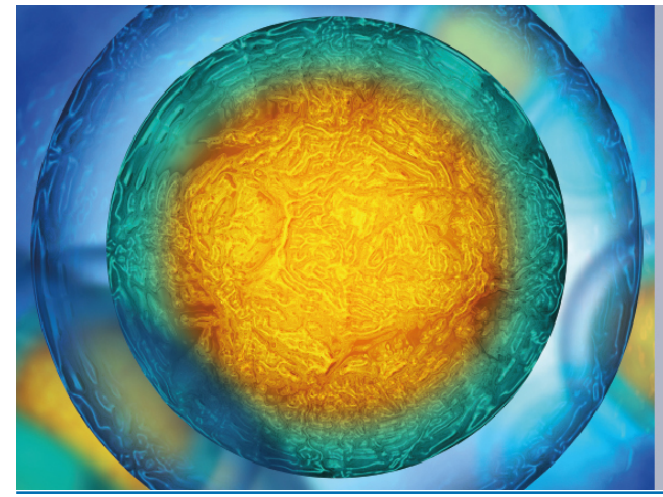

Biophysical Society $\quad$ IOP $\mid$ ebookS $^{\text {TM }}$ $\overline{\overline{\equiv \overline{\bar{\equiv}}}}$

Your publishing choice in all areas of biophysics research.

Start exploring the collection-download the first chapter of every title for free. 


\title{
Biofabrication
}

\section{PAPER}

CrossMark

\section{Additive manufactured polymeric 3D scaffolds with tailored surface topography influence mesenchymal stromal cells activity}

RECEIVED
21 January 2016

REVISED

19 April 2016

ACCEPTED FOR PUBLICATION

3 May 2016

PUBLISHED

24 May 2016

\author{
Sara C Neves ${ }^{1,2,3,4,5}$, Carlos Mota $^{4,5}$, Alessia Longoni ${ }^{4,8}$, Cristina C Barrias ${ }^{1,2,6}$, Pedro L Granja ${ }^{1,2,3,6}$ and \\ Lorenzo Moroni ${ }^{4,5,7,9}$ \\ 1 i3S-Instituto de Investigação e Inovação em Saúde, Universidade do Porto, Portugal \\ 2 INEB - Instituto de Engenharia Biomédica, Universidade do Porto, Portugal \\ 3 FEUP_Faculdade de Engenharia da Universidade do Porto, Departamento de Engenharia Metalúrgica e de Materiais, Portugal \\ 4 MIRA-Institute for Biomedical Technology and Technical Medicine, Department of Tissue Regeneration, University of Twente, \\ The Netherlands \\ 5 MERLN_-Institute for Technology Inspired Regenerative Medicine, Department of Complex Tissue Regeneration, Maastricht \\ University, The Netherlands \\ 6 ICBAS - Instituto de Ciências Biomédicas Abel Salazar, Universidade do Porto, Portugal \\ 7 CNR NANOTEC-Institute of Nanotechnology, c/o Campus Ecotekne, Università del Salento, Italy \\ 8 Current address: Department of Oral and Maxillofacial Surgery, University Medical Center Utrecht, Heidelberglaan 100, 3508 GA, \\ Utrecht, The Netherlands. \\ 9 Author to whom any correspondence should be addressed. \\ E-mail:1.moroni@maastrichtuniversity.nl
}

Keywords: additive manufacturing, wet-spinning, scaffolds, roughness, topography, human mesenchymal stromal cells

Supplementary material for this article is available online

\begin{abstract}
Additive manufactured three-dimensional (3D) scaffolds with tailored surface topography constitute a clear advantage in tissue regeneration strategies to steer cell behavior. 3D fibrous scaffolds of poly (ethylene oxide terephthalate)/poly(butylene terephthalate) block copolymer presenting different fiber surface features were successfully fabricated by additive manufacturing combined with wet-spinning, in a single step, without any post-processing. The optimization of the processing parameters, mainly driven by different solvent/non-solvent combinations, led to four distinct scaffold types, with average surface roughness values ranging from $0.071 \pm 0.012 \mu \mathrm{m}$ to $1.950 \pm 0.553 \mu \mathrm{m}$, average pore sizes in the $x$ - and $y$-axis between $351.1 \pm 33.6 \mu \mathrm{m}$ and $396.1 \pm 32.3 \mu \mathrm{m}$, in the $z$-axis between $36.5 \pm 5.3 \mu \mathrm{m}$ and $70.7 \pm 8.8 \mu \mathrm{m}$, average fiber diameters between $69.4 \pm 6.1 \mu \mathrm{m}$ and $99.0 \pm 9.4 \mu \mathrm{m}$, and porosity values ranging from $60.2 \pm 0.8 \%$ to $71.7 \pm 2.6 \%$. Human mesenchymal stromal cells (hMSCs) cultured on these scaffolds adhered, proliferated, and produced endogenous extracellular matrix. The effect of surface roughness and topography on hMSCs differentiation was more evident for cells seeded at lower density, where the percentage of cells in direct contact with the surface was higher compared to more densely seeded scaffolds. Under osteogenic conditions, lower surface roughness values $(0.227 \pm 0.035 \mu \mathrm{m})$ had a synergistic effect on hMSCs behavior, while chondrogenesis was favored on rougher surfaces $(1.950 \pm 0.553 \mu \mathrm{m})$.
\end{abstract}

\section{Introduction}

The core concept in tissue engineering (TE) is the combination of cells and/or biologically active cues with a supporting structure, in order to obtain a functional construct that will aid the repair or regeneration of the desired tissues [1,2]. These supporting structures can either be (i) scaffolds, which are porous networks on which cells are laid, or (ii) hydrogel-like matrices, within which cells are embedded. Besides their supportive role, these three-dimensional (3D) structures might promote important cellular activities including proliferation, migration and differentiation $[1,2]$. Consequently, the scaffolds and matrices material(s), as well as their structural properties, are of outmost importance as they can directly influence cellular activities.

Scaffolds can be processed in order to instruct cell behavior through their physico-chemical properties. 
Controlling cell activity by exploiting only the physical properties of the scaffolds presents major benefits such as manufacturing costs and stability, compared to chemical (bio)functionalization [3]. The latter usually requires more complex technological manipulation, higher costs, a reduced shelf-life, and an increased associated regulatory load when products are brought into clinic [3]. Mesenchymal stromal cells (MSCs) are currently one of the most promising cell types in the regenerative medicine field mainly for their multi-lineage differentiation capacity under specific culture conditions [4]. Several works suggest that MSCs may be guided to differentiate along a specific lineage by substrate physical properties like surface topography and roughness [5-10]. However, most of these studies have been performed in twodimensional (2D) substrates, while it is currently wellknown that cells behave differently when cultured in a 3D environment [11]. There are just a few works reporting the impact of the surface physical cues of polymeric 3D scaffolds on MSCs behavior [3, 12]. Typically, the scaffolds used in these studies required several fabrication steps to obtain the final structure with a defined surface topography.

Additive manufacturing (AM) techniques have been used to obtain scaffolds with well-defined geometries, starting from computer-aided design models [2, 13]. The concomitant development of biomaterials that can be used with these techniques allowed the fast development of this field, enabling the fabrication of scaffolds with tunable and reproducible properties $[1,2]$. Some of these AM techniques consist on the $3 \mathrm{D}$ deposition of consecutive layers of biomaterials in a controlled manner, in order to obtain a macroporous structure. The most common approach to obtain these structures is fused deposition modeling (FDM) [14, 15], which consists on the extrusion of a molten polymer through a nozzle, controlling the extruded polymer fiber deposition using a computer-aided manufacturing system. However, there is a limited number of biomaterials that can be processed by FDM due to the high temperatures needed to melt the material and the consequent narrow processing window due to thermal degradation. An alternative way to obtain biomaterial fibers is wet-spinning, a non-solvent induced phase separation (NIPS) technique that allows the processing of several natural and synthetic polymers [16-21], and the incorporation of bioactive agents on the polymer fibers that are temperature sensitive but stable in the solvents used $[22,23]$. Some of the initial wet-spinning studies aimed at the manufacturing of TE scaffolds composed of randomly oriented fibers, manually deposited in a non-solvent [17], or by using a two-step method, in which the obtained fibers are later physically bound together [16]. In order to precisely control the fiber deposition, recent studies proposed the combination of AM with wet-spinning, also termed computer-aided wet-spinning [24, 25], to accurately deposit biomaterial fibers layer-by-layer, thus achieving a good control over the internal architecture and external shape $[19,20,26]$.

Although AM scaffolds have been extensively studied, the evaluation of cell behavior and tissue built-up triggered by surface morphology in 3D is often ignored. Surface characteristics normally influence initial cellular activities like adhesion to the substrate, but, as referred, may also trigger further events like differentiation. Following the recent reappraisal of biofabrication approaches for TE and regenerative medicine [27], the fabrication through AM of smart scaffolds able to steer cell activity is considered a biofabrication strategy. In line with this, here we propose a biofabrication single-step method to obtain 3D scaffolds of poly(ethylene oxide terephthalate)/poly(butylene-terephthalate) (PEOT/ PBT) with a defined geometry by combining AM with wet-spinning. We show how the surface topography of the resulting scaffolds can be modulated just by varying the NIPS parameters. We used PEOT/PBT copolymer as this polyether-ester exhibit a wide range of physical properties like elasticity, toughness and strength, in combination with easy processability by changing the monomer ratio [28-31]; moreover, its clinical applicability has been recently assessed in humans [32]. The obtained 3D scaffolds were structurally characterized and in vitro studies were performed using human MSCs (hMSCs).

\section{Materials and methods}

\subsection{Fabrication of PEOT/PBT additive manufactured wet-spun scaffolds}

PEOT/PBT was provided by PolyVation B.V. (Groningen, The Netherlands). The composition used in this study was 300PEOT55PBT45, following the aPEOTbPBTc nomenclature, where ' $a$ ' is the molecular weight (in $\mathrm{g} \mathrm{mol}^{-1}$ ) of the starting PEG blocks used in the copolymerization, while ' $b$ ' and ' $c$ ' are the weight fractions of the PEOT and PBT blocks, respectively. PEOT/PBT was dissolved overnight either using anhydrous chloroform (CHL, SigmaAldrich) at room temperature (RT) or a mixture of CHL and dichloroethane (DCE, Sigma-Aldrich), in a $1: 1$ ratio at a temperature $\approx 35^{\circ} \mathrm{C}$, to obtain homogeneous solutions. Solutions were placed into a glass syringe fitted with a stainless steel blunt needle. Different needle sizes used in previous AM/wetspinning studies (G21, G22 or G23) were tested in order to allow further comparisons (data not shown). This initial screening led to the selection of a smaller needle size - G27 (inner diameter of $210 \mu \mathrm{m}$ ). A syringe pump (NE-1000, New Era Pump Systems Inc., USA) was used to control the extrusion flow rate of the polymer solution (figure 1(A)). A Teflon tube was used to connect the syringe to a support structure placed on 

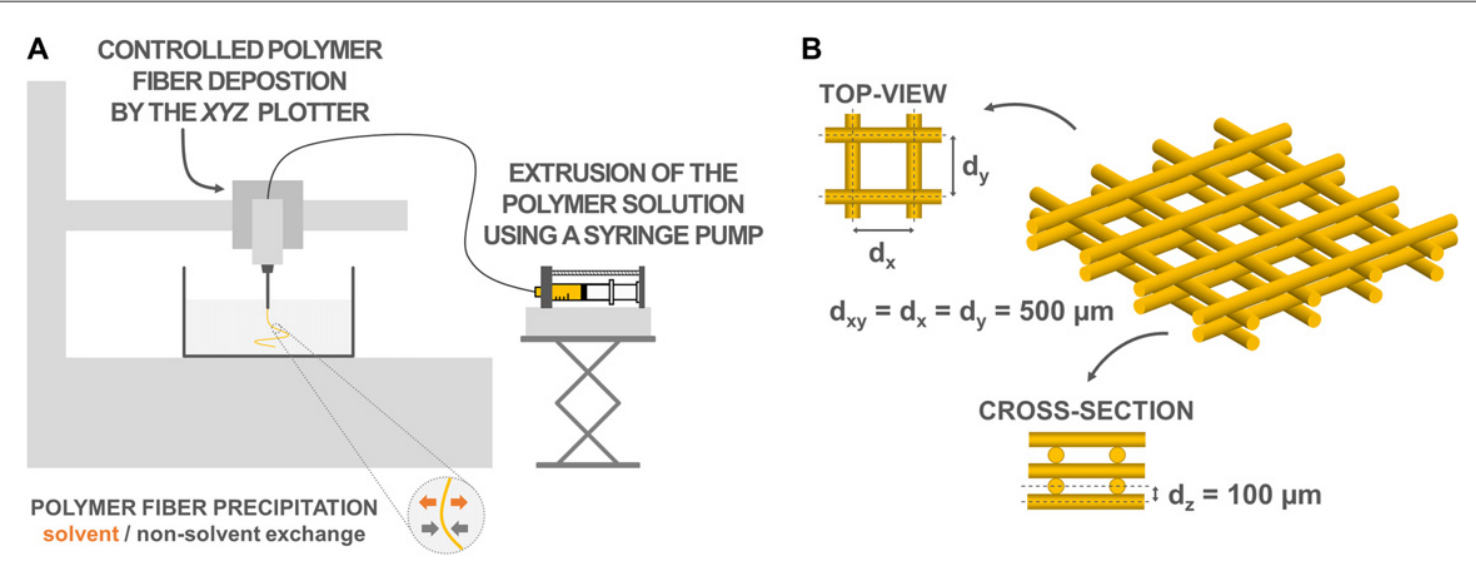

Figure 1. (A) Additive manufacturing wet-spinning technique and (B) the lay-down design used in this study to obtain the 3D scaffolds.

the plotter arm. This support structure connected the tube to the needle. A container was filled with each non-solvent isopropanol (ISOP, Sigma-Aldrich), ISOP in deionized water $\left(\mathrm{ddH}_{2} \mathrm{O}\right)(90 \mathrm{vol} \%)$, and ethanol (EtOH, Sigma-Aldrich) in $\mathrm{ddH}_{2} \mathrm{O}$ (90 or $80 \mathrm{vol} \%$ ) -, fixed to the fabrication platform, and used as precipitation bath. The extrusion temperature was controlled using a heating pad around the syringe and a heat control unit (Heater Kit, New Era Pump Systems Inc., USA). An initial distance $\left(Z_{0}\right)$ was set between the needle tip and the bottom of the container. The layer-by-layer fabrication of the scaffolds was performed using a 3D plotting machine (Envisiontec GmbH, Germany) as previously described [14, 33]. The lay-down design used in this study is shown in figure 1(B), with a distance between fibers in each layer $\left(d_{\mathrm{xy}}\right)$ of $500 \mu \mathrm{m}$, the angle between fibers on each layer of $90^{\circ}$, and the distance between layers $\left(d_{\mathrm{z}}\right)$ of $100 \mu \mathrm{m}$. The combination of the needle motion in all axes allowed the fabrication of scaffolds layer-by-layer. The processing conditions were optimized by varying the $d_{\mathrm{z}}$, the solution feed rate $(F)$ and the deposition velocity $\left(v_{\mathrm{dep}}\right)$. Table 1 summarizes the parameters used for the processing of the scaffolds.

After the plotting, the scaffolds were processed similarly to what previously described $[19,20,22,26]$. They were transferred to a fresh coagulation bath to complete the exchange between the solvent and the non-solvent. Then, the non-solvent excess was removed and the scaffolds were left to dry under the fume hood for $48 \mathrm{~h}$. For all studies, scaffolds were cored out from the manufactured rectangular prism-like structures with a $4 \mathrm{~mm}$ diameter biopsy cylinder punch (Integra ${ }^{\circledR}$ Miltex $^{\circledR}$ ).

\subsection{Characterization of the PEOT/PBT scaffolds}

\subsubsection{Scanning electron microscopy (SEM)}

All samples were gold sputtered (Cressington) prior to being analyzed by scanning electron microscopy (SEM, Philips XL 30 ESEM-FEG). Scaffolds from the in vitro studies (section 2.3) were dehydrated in a series of ethanol solutions $(50,60,70,80,90,96$ and $100 \mathrm{vol} \%$ in water), treated with hexamethyldisiloxane, and dried overnight, before being sputtered.

\subsubsection{Geometrical characterization}

The porosity $(P)$ was experimentally determined by using the measured mass $(m)$ and the volume $(V)$ of each scaffold [14] (equation (1)):

$$
P(\%)=[1-(m / V \rho)] \times 100,
$$

where $\rho$ is the specific density of the PEOT/PBT block copolymer $\left(1.2 \mathrm{~g} \mathrm{~cm}^{-3}\right)$.

The porosity of $3 \mathrm{D}$ plotted scaffolds was also calculated adapting the theoretical approach by Landers et al [34] (Supp. Info.), considering the fiber cross-sections as ellipses (equation (2)):

$$
\begin{aligned}
P(\%) & =\left(1-V_{\text {scaffold }} / V_{\text {cube }}\right) \times 100 \\
& =\left[1-\left(\pi d_{\mathrm{M}} d_{\mathrm{m}} / 4 d_{\mathrm{xy}} d_{\mathrm{z}}\right)\right] \times 100,
\end{aligned}
$$

where $d_{\mathrm{M}}$ is the fiber major diameter, $d_{\mathrm{m}}$ the fiber minor diameter, $d_{\mathrm{xy}}$ the fiber spacing and $d_{\mathrm{z}}$ the layer thickness. These geometrical parameters were measured from the SEM images using ImageJ software [35] (30 $d_{\mathrm{xy}}, 10 d_{\mathrm{z}}, 10 d_{\mathrm{M}}$ and $10 d_{\mathrm{m}}$ measurements in each of four independent scaffolds of each type).

\subsubsection{Fiber surface roughness measurements}

A 3D laser scanning microscope (VK-9700, Keyence, Japan) was used to image and measure the surface roughness of the scaffold fibers. A 100x objective was used to scan the samples with a $z$-pitch of $0.01 \mu \mathrm{m}$. Roughness measurements were performed in three scaffolds of each topography (one fiber per scaffold, six measurements per fiber). Data was analyzed using the VK Analyzer software (version 2.5.0.1, Keyence, Japan) and the arithmetic average roughness $\left(R_{\mathrm{a}}\right)$ and root mean squared roughness $\left(R_{\mathrm{RMS}}\right)$ were obtained.

\subsection{In vitro studies}

2.3.1. hMSCs culture

Human bone marrow-derived cells (hMSCs, Texas A\&M HSC, Institute for Regenerative Medicine, TX, 
Table 1. Additive manufacturing wet-spinning parameters used for the processing of the scaffolds.

\begin{tabular}{|c|c|c|c|c|c|c|}
\hline Designation & Solvent & Non-solvent & Extrusion temperature $\left({ }^{\circ} \mathrm{C}\right)$ & $Z_{0}(\mathrm{~mm})$ & $F\left(\mathrm{~mL} \mathrm{~h}^{-1}\right)$ & $v_{\mathrm{dep}}\left(\mathrm{mm} \mathrm{min}^{-1}\right)$ \\
\hline$S_{\mathrm{A}}$ & $\mathrm{CHL}$ & $\mathrm{EtOH}\left(80 \mathrm{vol} \%\right.$ in $\left.\mathrm{ddH}_{2} \mathrm{O}\right)$ & RT & 2.0 & 1.5 & 750 \\
\hline$S_{\mathrm{B}}$ & $\mathrm{CHL}$ & $\mathrm{EtOH}\left(90 \mathrm{vol} \%\right.$ in $\left.\mathrm{ddH}_{2} \mathrm{O}\right)$ & RT & 2.0 & 1.5 & 600 \\
\hline$S_{\mathrm{C}}$ & $\mathrm{CHL}$ & ISOP & RT & 2.0 & 1.5 & 600 \\
\hline$S_{\mathrm{D}}$ & CHL/DCE $(1: 1)$ & ISOP (90 vol\% in $\mathrm{ddH}_{2} \mathrm{O}$ ) & $35^{\circ} \mathrm{C}$ & 0.6 & 4.0 & 1200 \\
\hline
\end{tabular}

CHL: anhydrous chloroform; DCE: dichloroethane; EtOH: ethanol; ISOP: isopropanol; $\mathrm{ddH}_{2} \mathrm{O}$ : deionized water; $Z_{0}$ : initial distance from the needle tip to the bottom of the non-solvent container; $F$ : feed rate; $v_{\mathrm{dep}}$ : deposition velocity.

USA) were expanded in proliferation medium (PM) before the seeding of the scaffolds. PM consisted of basic medium (BM) containing $\alpha$-MEM (Gibco), $10 \mathrm{vol} \%$ of heat-inactivated fetal bovine serum (FBS, Gibco), L-glutamine (2 mM, Gibco), ascorbic acid (0.2 $\mathrm{mM}$, Sigma), penicillin (100 $\left.\mathrm{U} \mathrm{mL}^{-1}, \mathrm{Gibco}\right)$, and streptomycin $\left(100 \mu \mathrm{g} \mathrm{mL}^{-1}\right.$, Gibco), supplemented with basic fibroblast growth factor (bFGF, $1 \mathrm{ng} \mathrm{mL}^{-1}$, Instruchemie, the Netherlands). Cells were cultured at $37^{\circ} \mathrm{C}$, in a humidified atmosphere with $5 \% \mathrm{CO}_{2}$. Medium was refreshed every 2 days.

\subsection{2. hMSCs culture on the $3 D$ scaffolds}

Prior to cell seeding, the scaffolds were sterilized using either $70 \mathrm{vol} \%$ isopropanol or $70 \mathrm{vol} \%$ ethanol (according to the non-solvent used during the wet-spinning process) for at least $30 \mathrm{~min}$, washed three times with phosphate buffered saline (PBS), and then incubated in BM overnight. Cells were cultured until $70 \%-75 \%$ confluence and were used before passage three in all experiments. hMSCs were seeded on the scaffolds by placing a droplet of $10 \mu \mathrm{L}$ per scaffold containing two different cell quantities: 25000 and 125000 cells (from now referred to as low and high seeding densities, respectively). hMSCs were allowed to adhere before adding $500 \mu \mathrm{L}$ of BM per well. After $48 \mathrm{~h}$ in $\mathrm{BM}$, the culture medium was switched to either osteogenic medium, composed of BM supplemented with $10^{-8} \mathrm{M}$ of dexamethasone (Sigma-Aldrich) and $0.01 \mathrm{M}$ of $\beta$-glycerophosphate (Sigma-Aldrich), or chondrogenic medium, namely high glucose DMEM (Gibco) supplemented with insulin-transferrinselenium (ITS, $1 \mathrm{vol} \%$, Gibco), proline $(0.35 \mathrm{mM}$, Sigma-Aldrich), sodium pyruvate (1 vol\%, SigmaAldrich), ascorbic acid 2-phosphate $(0.20 \mathrm{mM}$, Sigma-Aldrich), penicillin (100 $\mathrm{U} \mathrm{mL}^{-1}$, Gibco), streptomycin (100 $\mu \mathrm{g} \mathrm{mL}^{-1}$, Gibco), transforming growth factor $\beta 3$ (TGF- $\beta 3,10 \mathrm{ng} \mathrm{mL} \mathrm{m}^{-1}$, R\&D Systems) and dexamethasone $\left(10^{-7} \mathrm{M}\right.$, Sigma-Aldrich). A set of samples was cultured in BM as control. Medium was changed every 2 days for up to 9 days of culture.

\subsubsection{Determination of hMSCs metabolic activity}

hMSCs metabolic activity was estimated using a resazurin-based assay (PrestoBlue ${ }^{\circledR}, \quad$ Molecular Probes). At the different time-points, culture medium was removed from the wells and fresh medium with 10 vol\% PrestoBlue ${ }^{\circledR}$ (Sigma-Aldrich) was added.
Cell-loaded scaffolds were incubated $\left(37^{\circ} \mathrm{C}, 5 \% \mathrm{CO}_{2}\right)$ for $2 \mathrm{~h}$, after which $200 \mu \mathrm{L} /$ well were transferred to a black 96 well plate and the fluorescence was measured $\left(\lambda_{\mathrm{ex}} \approx 535 \mathrm{~nm}, \lambda_{\mathrm{em}} \approx 560 \mathrm{~nm}\right)$ using a plate reader (Victor ${ }^{3}$, Perkin Elmer).

\subsubsection{Biochemical analyses}

For each time-point, cell culture media was removed from the samples, gently washed with PBS, and stored at $-80{ }^{\circ} \mathrm{C}$ (without PBS) for at least $24 \mathrm{~h}$. After thawing, the samples were incubated in a lysis buffer (consisting of $0.1 \mathrm{M} \mathrm{KH}_{2} \mathrm{PO}_{4}, 0.1 \mathrm{M} \mathrm{K}_{2} \mathrm{HPO} 4$ and 0.1 vol\% Triton X-100, at $\mathrm{pH} 7.8$ ) for $1 \mathrm{~h}$ at RT. Using the resultant lysate, the following analyses were performed.

(a) Measurement of alkaline phosphatase (ALP) activity

ALP activity was evaluated by a chemoluminescence assay (CDP-star ${ }^{\circledR}$ kit, Roche). Briefly, $40 \mu \mathrm{L}$ of CDP-Star reagent were added to $10 \mu \mathrm{L}$ of the lysate. After $15 \mathrm{~min}$ of incubation at RT in the dark, the chemoluminescence was measured with the previously mentioned plate reader.

\section{(b) Total DNA quantification}

The cell lysate was mixed (1:1 volume ratio) with a digestion buffer (Tris/EDTA buffer, $\mathrm{pH} 7.6$, containing proteinase $\mathrm{K}\left(1 \mathrm{mg} \mathrm{mL}^{-1}\right.$, Sigma-Aldrich), iodoacetamine $\left(0.185 \mathrm{mg} \mathrm{mL}^{-1}\right.$, Sigma-Aldrich) and pepstatin A (0.01 $\mathrm{mg} \mathrm{mL}^{-1}$, Sigma-Aldrich) ) and incubated for $16 \mathrm{~h}$ at $56^{\circ} \mathrm{C}$. The total DNA was quantified using the CyQuant ${ }^{\circledR}$ DNA assay (Molecular Probes) following the manufacturer's instructions, measuring the fluorescence with the previously mentioned plate reader $\left(\lambda_{\mathrm{ex}} \approx 480 \mathrm{~nm}, \lambda_{\mathrm{em}} \approx 520 \mathrm{~nm}\right)$, and using a DNA standard curve.

\section{(c) Glycosaminoglycans (GAGs) quantification}

The GAGs amount was determined spectrophotometrically after the reaction of the lysate with a dimethylmethylene blue dye solution (DMMB, Sigma-Aldrich, in a $9.5 \mathrm{mM} \mathrm{HCl}$ solution containing $3.04 \mathrm{~g} \mathrm{~L}^{-1}$ of glycine and $2.37 \mathrm{~g} \mathrm{~L}^{-1}$ of $\mathrm{NaCl}$, at $\mathrm{pH} 3$ ) [36]. A microplate spectrophotometer (Multiskan ${ }^{\mathrm{TM}}$ 
GO, Thermo Fisher) was used to determine the absorbance at $\lambda \approx 525 \mathrm{~nm}$. The amount of GAG was calculated using a standard curve of known concentrations of chondroitin sulfate (SigmaAldrich).

\subsubsection{Gene expression analysis}

The cell culture media was removed from the wells and the samples were carefully washed two times with PBS. Samples were transferred to Eppendorf ${ }^{\circledR}$ tubes and TRIzol ${ }^{\oplus}$ (Invitrogen) was added prior to preservation at $-80{ }^{\circ} \mathrm{C}$ for at least $24 \mathrm{~h}$. After thawing, $200 \mu \mathrm{L}$ of CHL (Sigma-Aldrich) were added to each sample and mixed by vigorously vortexing the tubes. The TRizol ${ }^{\circledR} / \mathrm{CHL}$ mixture was centrifuged at $12000 \mathrm{~g}$ for $20 \mathrm{~min}$ at $4{ }^{\circ} \mathrm{C}$. Afterwards, the RNA-containing phase was transferred to a new Eppendorf ${ }^{\circledR}$ tube and mixed 1:1 with 70 vol\% ethanol. The mixture was then transferred to filter columns provided by the RNA isolation kit (ISOLATE II RNA mini kit, Bioline) and the subsequent steps were performed according to the manufacturer's instructions. RNA was eluted in $40 \mu \mathrm{L}$ of RNAse-free water and its concentration and purity were determined using a spectrophotometer (NanoDrop 1000, Thermo Scientific). The cDNA was synthesized using iScript ${ }^{\mathrm{TM}}$ (Bio-Rad) according to the manufacturer's protocol. Quantitative polymerase chain reaction (qPCR) was performed using the obtained cDNA by using the iQ SYBR Green Supermix (Bio-Rad) and the primers listed in table 2. PCR reactions were performed using CFX Connect ${ }^{\mathrm{TM}}$ Real-Time System (Bio-Rad) and analyzed with Bio-Rad iQ5 optical system software. The obtained CT values were normalized for the ones of the housekeeping gene (B2M).

\subsection{Statistical analyses}

Statistical analyses were performed using GraphPad Prism software, using a non-parametric unpaired test (Mann-Whitney), with a 95\% confidence interval. Statistically significant differences are specified on the figure caption of the corresponding data.

\section{Results}

\subsection{Optimization of scaffolds processing}

The scaffolds optimization process was divided in two main steps. The first one corresponded to the wet-spinning of PEOT/PBT solutions, in which we aimed at testing different PEOT/PBT solvent/nonsolvent combinations to obtain continuous and uniform polymer fibers with different surface topographies. The second step corresponded to the optimization of the AM step, i.e. the controlled layerby-layer deposition of the optimized fibers in order to obtain consistent 3D structures and avoid the delamination of the fibers in the fiber-to-fiber contact points (during the processing and after drying the structures), thus ensuring that the scaffolds would have open pores in all axes. Different solvents/nonsolvents of the PEOT/PBT were tested (supplementary information tables 1 and 2), but the more consistent fibers were obtained using CHL (alone or in combination with DCE) as solvent, and ethanol, isopropanol, or mixtures of these with ultrapure water as non-solvents. The optimal polymer solution concentrations were 15 and $20 \mathrm{wt} \%$ (supplementary information table 2). Figure 2 shows examples of the different surface topographies that could be obtained when using different solvent/non-solvent combinations. These candidates were then tested for consistent 3D layer-by-layer deposition using a 3D plotter (figure 1(A)), by varying one AM parameter at a time (e.g., the needle tip initial distance from the bottom of the non-solvent container, $Z_{0}$ ), while keeping all the other parameters constant ( $v_{\mathrm{dep}}, F, d_{\mathrm{xy}}, d_{\mathrm{z}}$ ), including the lay-down design (figure 1(B)) (rectangular prismlike shape, with the same number of layers). Despite the range of different surface topographies that could be obtained just by varying the NIPS parameters (figure 2), the combinations and fabrication parameters (supplementary information table 3) that allowed a more homogeneous and consistent scaffold fabrication (figures 2(A), (B), (E) and (H)) are presented in table 1 , and were used for further studies. The four types of scaffolds $\left(S_{\mathrm{A}}, S_{\mathrm{B}}, S_{\mathrm{C}}\right.$ and $\left.S_{\mathrm{D}}\right)$ were named after the surface roughness measurements, from the lowest to the highest $R_{\mathrm{a}}$ values.

\subsection{D scaffolds characterization}

The geometrical properties of the scaffolds $\left(d_{\mathrm{M}}, d_{\mathrm{m}}\right.$, $d_{\mathrm{xy}}$ and $d_{\mathrm{z}}$ ) were measured from the SEM images (figure 3). These were used for the calculation of the scaffolds theoretical porosity (figure 4(A), $T$ values), which ranged from $69.4 \%$ to $84.3 \%$. The porosity calculated using the mass measurements ranged from $60.2 \%$ to $71.7 \%$ ((figure $4(\mathrm{~A}), M$ values). The distances $d_{\mathrm{xy}}$ and $d_{\mathrm{z}}$ were significantly different $(p<0.05)$ between scaffolds, except between $S_{\mathrm{C}} / S_{\mathrm{B}}$ and $S_{\mathrm{C}} / S_{\mathrm{D}}$ (for $d_{\mathrm{xy}}$ ). When compared to the original design, and after drying, the scaffolds had a shrinkage in the range of $21 \%-30 \%$ in the $x y$ plane and in the range of $29 \%-64 \%$ in the $z z$ plane. It is possible to observe that the different scaffolds have similar macrostructures, and that the major difference relies on the fibers surface topography. This was characterized by laser scanning microscopy (figure 4(B)), and four significantly different $(p<0.05)$ surface roughness values could be obtained: $0.071 \pm 0.012 \mu \mathrm{m}\left(S_{\mathrm{A}}\right), 0.105 \pm$ $0.016 \mu \mathrm{m}\left(S_{\mathrm{B}}\right), 0.227 \pm 0.035 \mu \mathrm{m}\left(S_{\mathrm{C}}\right), 1.950 \pm$ $0.553 \mu \mathrm{m}\left(S_{\mathrm{D}}\right)$. In general, no significantly different roughness values were found between scaffolds of the same type (supplementary information figure S1A). Besides the different surface roughness values, from the SEM images it can be observed that the $S_{\mathrm{D}}$ scaffolds 
Table 2. Primers used in the study.

\begin{tabular}{lll}
\hline Gene & Forward primer & Reverse primer \\
\hline B2M & 5'ACAAAGTCACATGGTTCACA-3' $^{\prime}$ & 5'-GACTTGTCTTTCAGCAAGGA-3' $^{\prime}$ \\
RUNX2 & $5^{\prime}$-TGGTTACTGTCATGGCGGGTA-3' & $5^{\prime}$-TCTCAGATCGTTGAACCTTGCTA-3' \\
BSP & $5^{\prime}$-CCCCACCTTTTGGGAAAACCA-3' & $5^{\prime}$-TCCCCGTTCTCACTTTCATAGAT-3' \\
SOX9 & 5'-TGGGCAAGCTCTGGAGACTTC-3' $^{\prime}$ & $5^{\prime}$-ATCCGGGTGGTCCTTCTTGTG-3' \\
COL2A1 & $5^{\prime}$-CGTCCAGATGACCTTCCTACG-3' & $5^{\prime}$-TGAGCAGGGCCTTCTTGAG-3' \\
\hline
\end{tabular}

have a surface topography quite different from the other scaffold types.

\section{3. hMSCs activity on the $3 \mathrm{D}$ scaffolds}

The hMSCs seeded on the scaffolds were able to adhere, as observed from the SEM images (figure 5(A)) and from the DNA quantification (figure 5(B)). Cell quantity was higher for the higher cell seeding density. hMSCs also presented a similar morphology, although hMSCs on the $S_{\mathrm{C}}$ scaffolds presented a more spindlelike shape. Cells were metabolically active for all seeding densities and scaffold types (figure 5(B)), but metabolic activity levels were significantly higher for cells seeded at the lower seeding density. Throughout the 9 days of culture (figure 5(C)), cells proliferated differently when comparing the different cell seeding densities; for the low seeding density, cell number increased in all scaffold types. For the high seeding density, cell number remained essentially unaltered. Representative images of hMSCs colonization of the scaffolds after 9 days of culture are presented on figure 6. Only SEM images of the scaffolds seeded with a low density are presented, since for the high seeding density scaffolds were fully covered after 9 days of culture and no differences could be visually observed. hMSCs colonized the scaffolds mainly in a radial way under basic and osteogenic conditions, and had some tendency to aggregate under chondrogenic conditions. In general, and after 9 days of culture, differences in ALP activity, GAG production, and gene expression (figure 7) were more evident between scaffolds that were seeded with a low cell density than with a high cell density. Among the scaffolds seeded with a lower cell density, the hMSCs cultured under osteogenic conditions presented a lower ALP activity, but higher RUNX2 gene expression on the $S_{\mathrm{C}}$ scaffolds. The BSP gene expression was low but similar between the scaffold types with surface roughness $\leqslant S_{\mathrm{C}}$. Interestingly, it seemed that below a threshold value of $\approx 0.227 \mu \mathrm{m}$, either gene expression or ALP activity was influenced by surface roughness in synergy with osteogenic media. The effect of surface topography on hMSCs differentiation was more evident and clear for the culture under chondrogenic conditions, where significantly higher GAG production and expression of SOX9 and COL2A1 were observed on the roughest scaffolds.

\section{Discussion}

The main aim of the current study was the optimization of a single step process based on AM and wet-spinning to produce polymer fibers with a wide range of surface topographies and roughness values. This process has been previously described for the manufacturing of linear poly( $\varepsilon$-caprolactone $)$ (PCL) [26], star shape PCL ( $\left.{ }^{*} \mathrm{PCL}\right)[19,37]$ and poly [(R)-3-hydroxybutyrate-co-(R)-3-hydroxyhexanoate] (PHBHHx) [20] scaffolds for bone TE. The same technique was herein investigated for the fabrication of PEOT/PBT scaffolds with similar macrostructure, but different fiber surface topographies, in just one processing step.

The first part of the study focused on the optimization of the extrusion process based on NIPS, which led to a set of optimal parameters as previously described (table 1). During this process, a homogeneous (thermodynamically stable) polymer solution is transformed into a polymer-rich phase (a high polymer concentration), and a polymer-poor phase (a high solvent concentration) to minimize the Gibbs free energy of mixing of the system [38, 39]. The thermodynamic interactions between polymer/ solvent/non-solvent and the concentration/phase changes that occur during phase inversion are often illustrated using the ternary phase diagrams $[38,40]$. When this demixing occurs, polymer fibers with a specific surface topography are obtained.

Apart from fabricating PEOT/PBT scaffolds using the combination of AM with wet-spinning for the first time, we intended to explore the capability of wet-spinning for the production of polymer fibers with surface physical properties resultant from the process itself, without recurring to any kind of post-processing, in a similar way as bioactive factors are incorporated during the fabrication of wet-spun scaffolds [19, 22, 37, 41]. Based on the nature of the NIPS technique and the insight provided by previous works on polymer substrates or strands, where the combination of parameters dictates the final fiber surface and cross-sectional morphologies [19, 42, 43], we were able to obtain a set of PEOT/PBT polymer fibers with different surface topographies. Some of the NIPS studies using other polymers like polystyrene-blockpoly(4-vinylpyridine) [43], PCL [26], *PCL [19, 37], PHBHHx [20], poly(L-lactic acid) [42] or poly (vinylidene fluoride) [44] report a porous cross- 

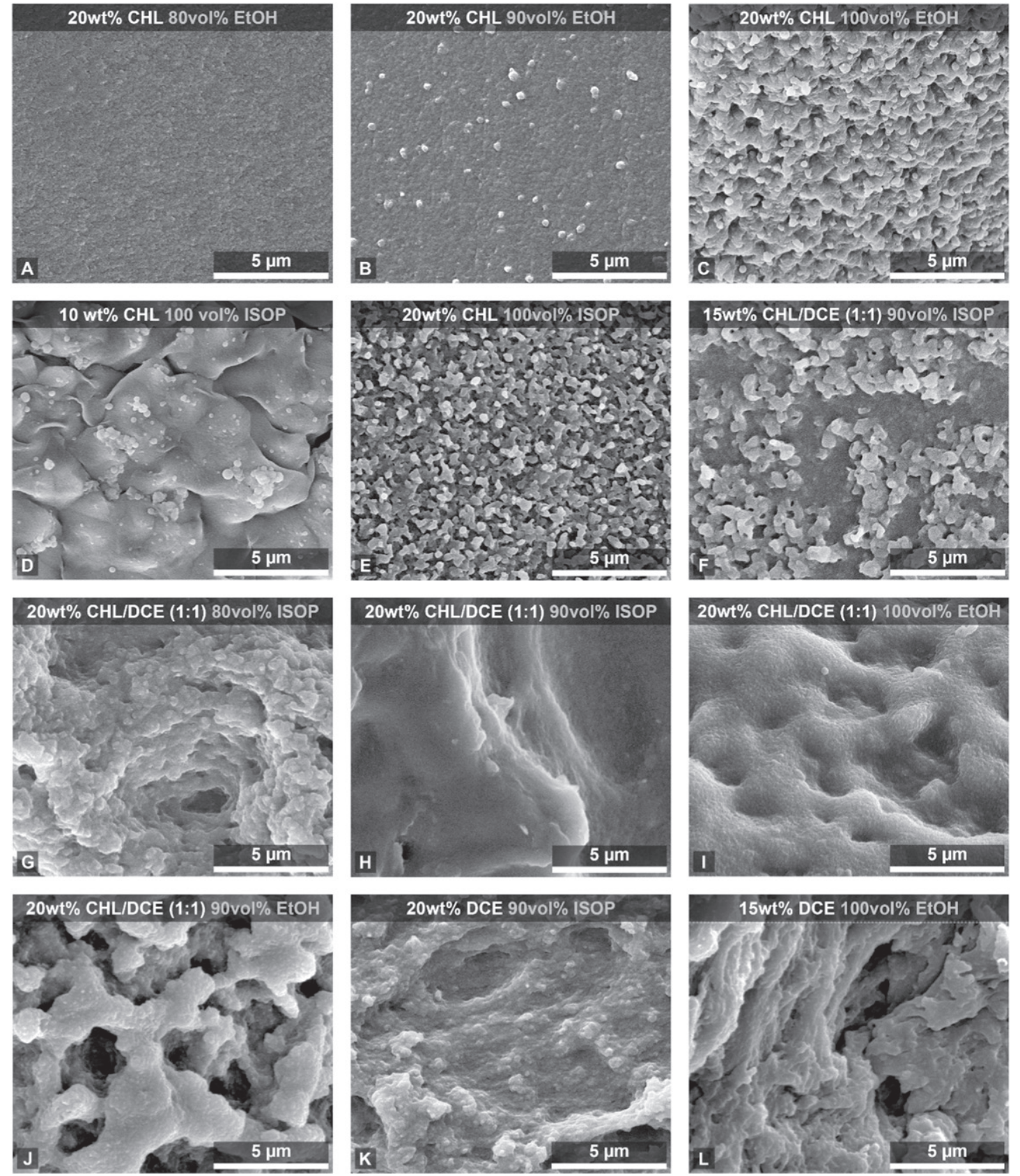

CHL: chloroform DCE: dichloroethane ISOP: isopropanol EtOH: ethano

Figure 2. Scanning electron microscopy (SEM) images of examples of surface topographies obtained using different PEOT/PBT solvent/non-solvent combinations (specified on top of each).

sectional morphology. Differently, the structures that we obtained did not present an internal nor external porous morphology, but a dense internal structure with different surface topographies. This compact internal structure was also previously reported for fibers of cellulose [45, 46], silk fibroin [47], silk fibroin/poly(vinyl alcohol) blends [48] or polyacrylonitrile [49]. Although not previously described specifically for PEOT/PBT, we hypothesize that the internal dense structure resulted from the same phenomena described by Um et al [47]. The cross-sectional morphology of wet-spun fibers results from the combination of several parameters, where the coagulation rate, which includes both the diffusion rate of the coagulant and the precipitation strength of coagulation, is among the most important ones. Generally, a high rate of coagulation leads to a porous cross-sectional morphology, while a slow rate yields a more dense structure [47]. It is well described in literature that structures with internal voids usually also present porous surface morphologies $[19,20,26,37,42-44]$. However, little is known 


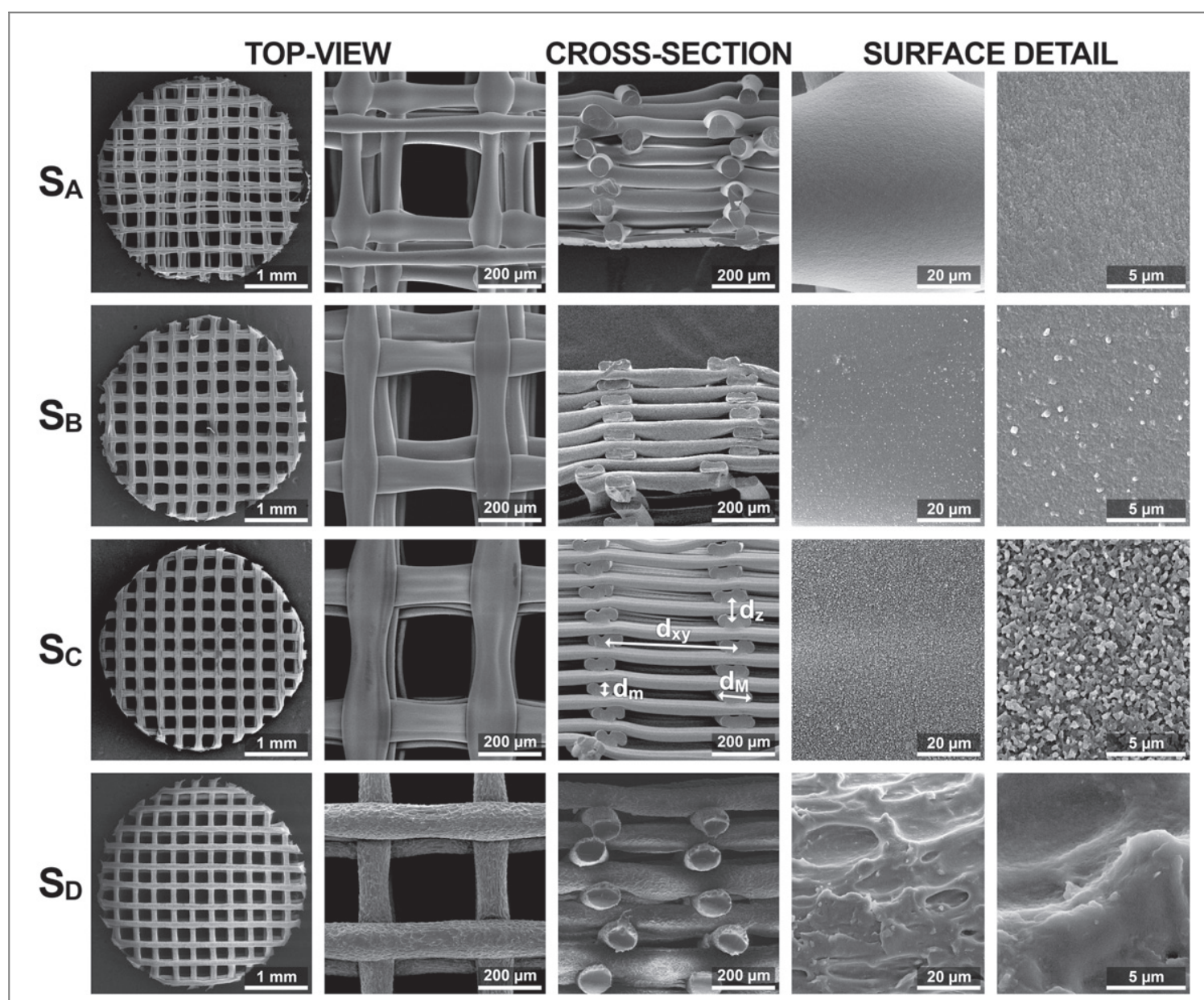

Figure 3. Scanning electron microscopy (SEM) images of the scaffolds. The scaffolds' fibers major $\left(d_{\mathrm{M}}\right)$ and minor $\left(d_{\mathrm{m}}\right)$ diameters and fiber spacing $\left(d_{\mathrm{xy}}\right.$ and $\left.d_{\mathrm{z}}\right)$ are identified on the cross-section of the scaffold type $S_{\mathrm{C}}$.

regarding fibers obtained by NIPS displaying internal compact cross-section and, at the same time, surface features similar to those that we have obtained. Park et al [50] described different morphological features at the surface of for poly(L-lactic acid)/pluronic blend films obtained by a NIPS technique, and we hypothesize that the main factor leading to the surface features that we observed in our fibers results from the same phenomenon, mainly driven by the polymer used and the solvent/non-solvent exchange.

The wider initial set of solvent/non-solvent combinations was narrowed down to the four presented in table 1, as they allowed the most homogeneous, consistent, and reproducible scaffolds fabrication. The processing window of the optimized conditions was also exquisitely defined (supplementary information tables 1-3). For example, keeping all other parameters constant, a decrease of $20 \%$ on the fiber deposition speed $\left(v_{\text {dep }}\right)$ or increasing the feed rate ( $F$ ) for $25 \%$ led to collapsed pores in the $z$-axis; a layer thickness $\left(d_{\mathrm{z}}\right)$ higher than $100 \mu \mathrm{m}$ led to the nonattachment of the fibers in the fiber-to-fiber contact points, or to the detachment of the fibers from each other after drying of the fabricated structure. In addition to the surface morphology, the AM wet-spinning process also intrinsically influenced the dimensions of the polymer fibers formed. The shrinkage observed in all planes of the produced PEOT/PBT scaffolds was mainly caused by the demixing process itself. When the polymer solution enters in contact with the nonsolvent and the precipitation process occurs, the solvent present in the polymer solution disperses into the non-solvent. Moreover, during plotting, the drag forces in the interface between non-solvent and the forming fiber induces stretching of the fiber before it contacts the previously deposited layer. The combination of these factors led to polymer fibers thinner (average diameter: $69.4 \pm 6.1-99.0 \pm 9.4 \mu \mathrm{m}$ ) than the nominal inner diameter of the needle used $(210 \mu \mathrm{m})$. The ellipsoidal shape of the fibers cross-section is also a consequence of the deposition process, as the forming fiber is still partially liquid when it contacts the previously deposited layer. However, this phenomenon promotes the fiber-tofiber bonding: fibers would not attach to each other if the ones being wet-spun were fully precipitated when contacting the previously deposited ones.

Several studies report the development of PEOT/PBT porous structures as scaffolds for TE, either by FDM [14, 51] or electrospinning [52]. However, this is the first study reporting the fabrication of PEOT/PBT scaffolds by combining AM 

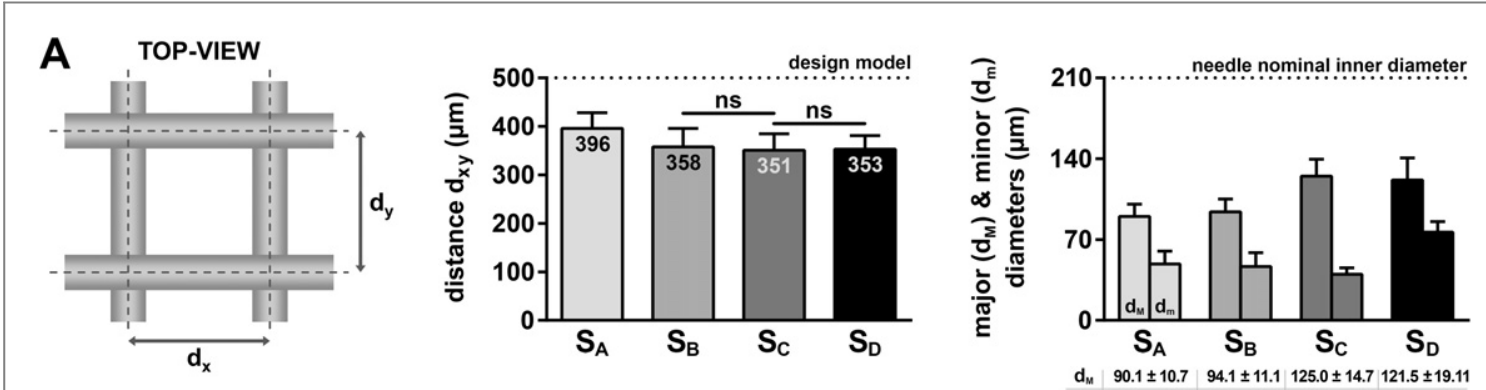

$d_{x y}=d_{x}=d_{y}=500 \mu m$
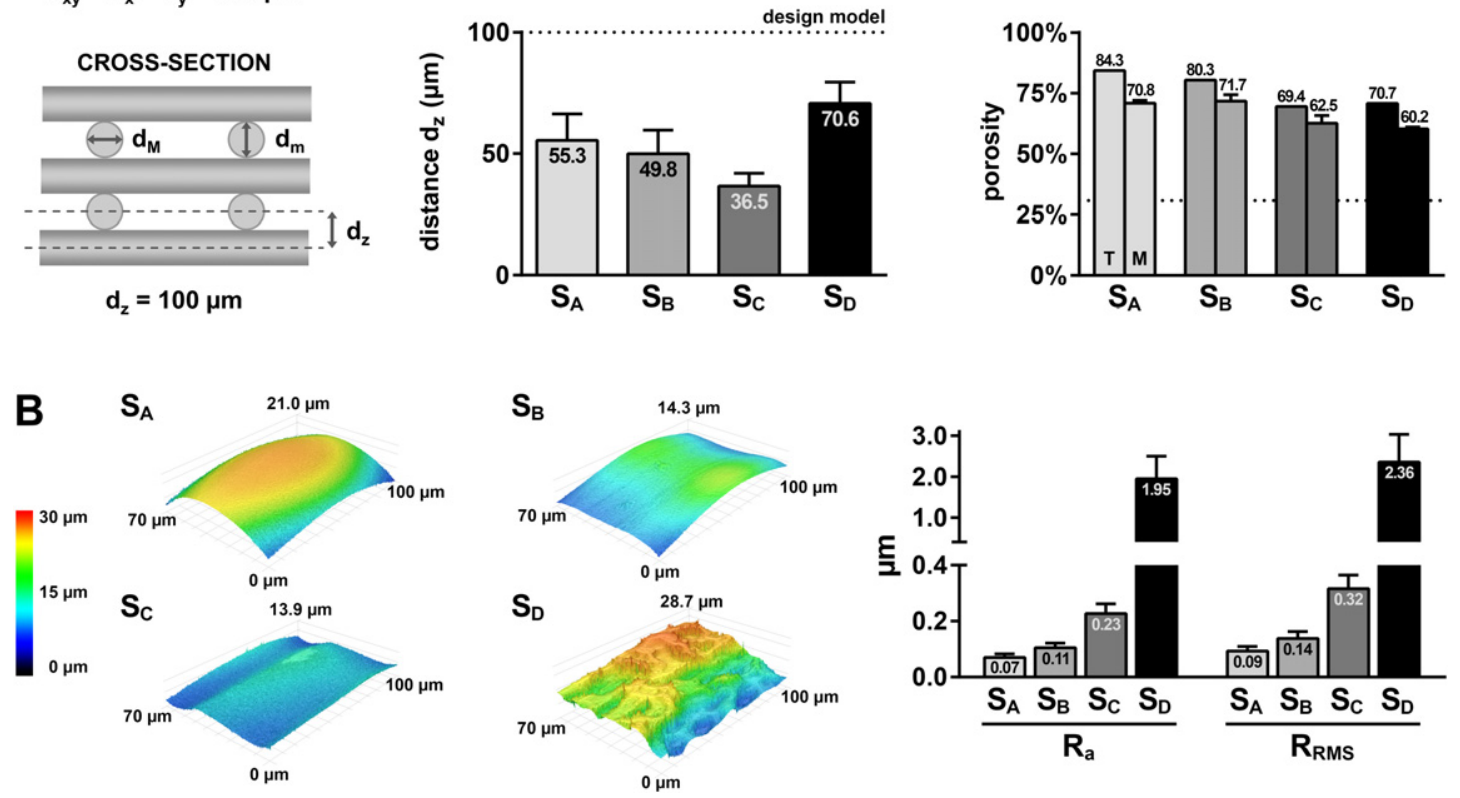

Figure 4. (A) Measurements of the scaffolds' fibers major $\left(d_{\mathrm{M}}\right)$ and minor $\left(d_{\mathrm{m}}\right)$ diameters, fiber spacing $\left(d_{\mathrm{xy}}\right.$ and $\left.d_{\mathrm{z}}\right)$ from the scanning electron microscopy (SEM) images, and porosity, where $T$ represents the theoretically calculated value using equation (2) (Landers et al [34]), and $\mathbf{M}$ the value obtained from the measured mass and volume of the scaffolds, calculated by equation (1) (Moroni et al [14]); the dotted line on each graph refers to the design model. (B) Height maps of the fiber surfaces obtained by scanning laser microscopy and the corresponding arithmetic average roughness $\left(R_{\mathrm{a}}\right)$ and root mean squared roughness $\left(R_{\mathrm{RMS}}\right)$. The $d_{\mathrm{xy}}$ and $d_{\mathrm{z}}$ of the different topographies are significantly different from each other with a $p<0.05$ unless otherwise stated with 'ns' (not significant); the $R_{\mathrm{a}}$ and $R_{\mathrm{RMS}}$ measurements of all topographies are statistically different from each other with a $p<0.0001$.

with wet-spinning. Here, 3D structures were successfully manufactured with average fiber diameters in the scale range between FDM scaffolds and electrospun matrices produced with the same polymer, and presenting slightly lower porosity values. For example, the fiber diameter of the scaffolds in the current study ranged from $69.4 \pm 6.1 \mu \mathrm{m}\left(S_{\mathrm{A}}\right)$ to 99.0 $\pm 9.4 \mu \mathrm{m}\left(S_{\mathrm{D}}\right)$ (average of the $d_{\mathrm{M}}$ and $d_{\mathrm{m}}$ values of each scaffold type), which is lower than the fiber diameter $(170 \pm 15 \mu \mathrm{m})$ reported for PEOT/PBT FDM scaffolds processed with a needle with a similar inner nominal diameter $(200 \mu \mathrm{m})$ [14, 51]. Electrospun fibers obtained from PEOT/PBT solutions [52] with a polymer mass concentration (20 and $18 \mathrm{wt} \%$ in $\mathrm{CHL}$ [52]) similar to the ones used in the current study present an average diameter of $21.4 \pm 6 \mu \mathrm{m}$ and $10 \pm$ $8 \mu \mathrm{m}$, which is lower than what we have obtained in the current work. When comparing the morphological characteristics of the scaffolds in the present study with the few reports of additive manufactured wetspun scaffolds, we could observe a closer resemblance to the morphological features of PHBHHx [20] scaffolds, which present slightly lower fiber diameters (47 $\pm 5-76 \pm 9 \mu \mathrm{m}$ using needles with inner nominal diameter of $410 \mu \mathrm{m}$ (G21)) and higher porosities (78.6\%-88.4\%), than the PCL additive manufactured wet-spun scaffolds, which present higher fiber diameters (189 $\pm 4-274 \pm 8 \mu \mathrm{m}$ [19], $223 \pm 29 \mu \mathrm{m}$ [37] and $202 \pm 12 \mu \mathrm{m}$ [26] using needles with inner nominal diameter of $337 \mu \mathrm{m}(\mathrm{G} 23)[19,26]$ and $410 \mu \mathrm{m}$ (G22) [37]), and lower porosities (20\%-60\%). The two methodologies used to calculate the porosity of the scaffolds in this work revealed distinct ranges. Porosities calculated with equation (1) are normally more representative of the real porosity as compared to the theoretical approaches (equation (2)). The porosities of the scaffolds obtained in the current work calculated with equation (1) $(60.2 \pm 0.8 \%$ to $71.7 \pm 2.6 \%)$ are slightly lower than reported porosities for PEOT/PBT FDM scaffolds [14] or PEOT/PBT electrospun matrices [52] (85.4\% and $83.0 \%$, respectively) calculated by the same method (equation (1)).

Overall, the combination of AM with wet-spinning preserves the typical advantages of the 
A
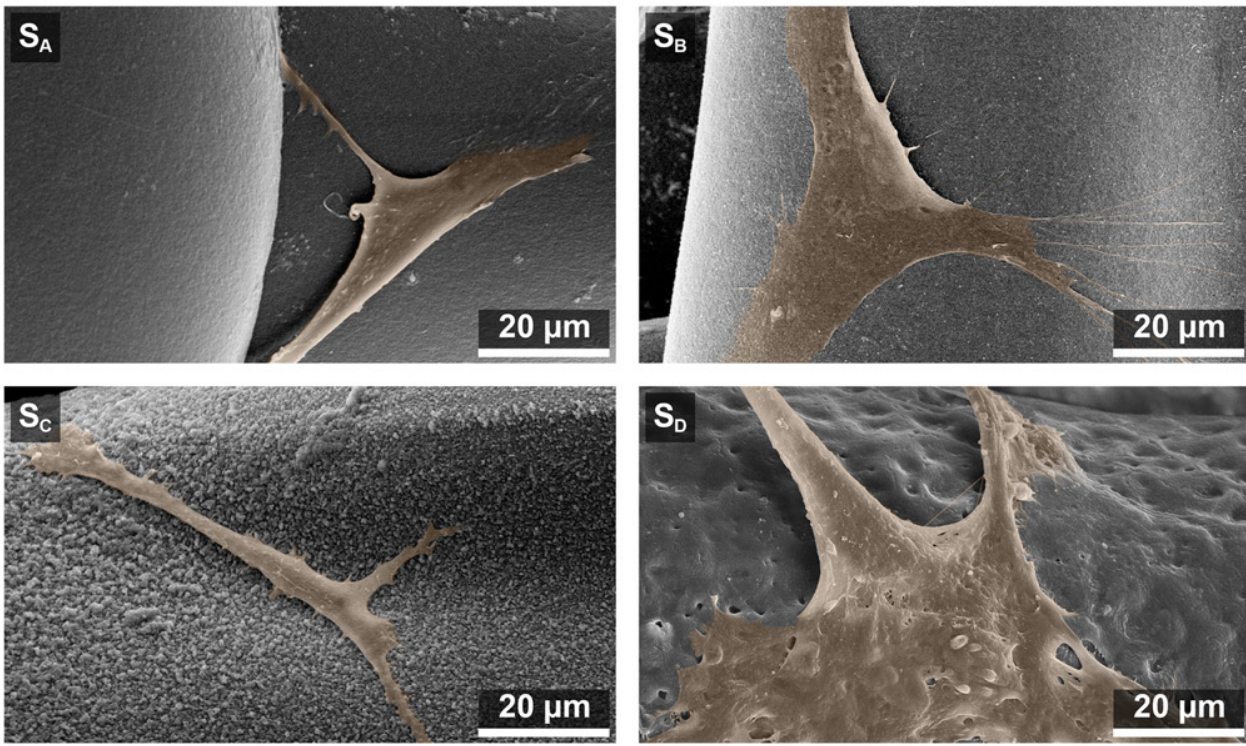

B

hMSCs activity after $24 \mathrm{~h}$
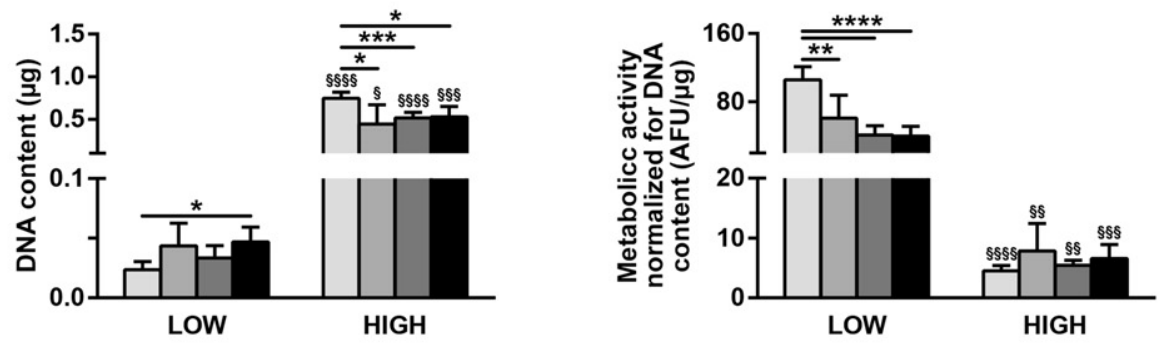

C

DNA content fold change from $24 \mathrm{~h}$ to day 9 of culture

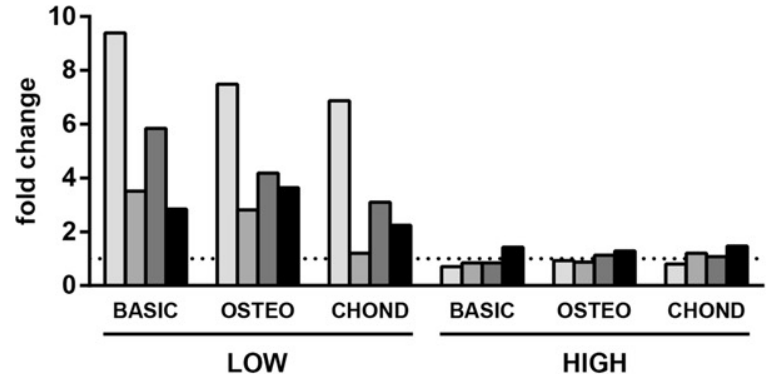

$\square \mathrm{S}_{\mathrm{A}} \square \mathrm{S}_{\mathrm{B}} \quad \square \mathrm{S}_{\mathrm{C}} \quad \square \mathrm{S}_{\mathrm{D}}$

Figure 5. (A) Morphology (by scanning electron microscopy), (B) DNA quantification and metabolic activity of human mesenchymal stromal cells (hMSCs, pseudo-colored orange) seeded on the different scaffold topographies after 24 h; (C) DNA fold change of the hMSCs seeded on the different scaffolds from $24 \mathrm{~h}$ to day 9 of culture (the last 7 days under basic or differentiation conditions). Low and high refer to the seeding densities ( 25000 and 125000 cells/scaffold, respectively). Statistically significant differences are marked with * $(p<0.05)$, ** $(p<0.01)$ or ${ }^{* * *}(p<0.001)$ when comparing different topographies seeded with the same cell density and ${ }^{\S}(p<0.05),{ }^{\$ \S}(p<0.01),{ }^{\$ \S \$}(p<0.001)$ or ${ }^{\$ \$ \$ \$}(p<0.0001)$ when comparing the same topography seeded with the two different cell densities.

FDM techniques comprising a customized 3D external shape, and controlled pore size and geometry [26]. Moreover, the polymer fibers obtained by wetspinning (using similar needle gauges) are thinner than the ones fabricated by FDM. Consequently, when comparing the same macrostructure volume, the AM wet-spun scaffolds usually present a higher porosity, which offers advantages like an increase on the degradation rate, increase of the mass transfer associated with chemical release, and increase in activity of seeded cells [19, 26, 53]. Wet-spinning may also allow to load the scaffolds with bioactive agents that have good stability in the solvents used, but that are sensitive to the high temperatures employed by FDM 


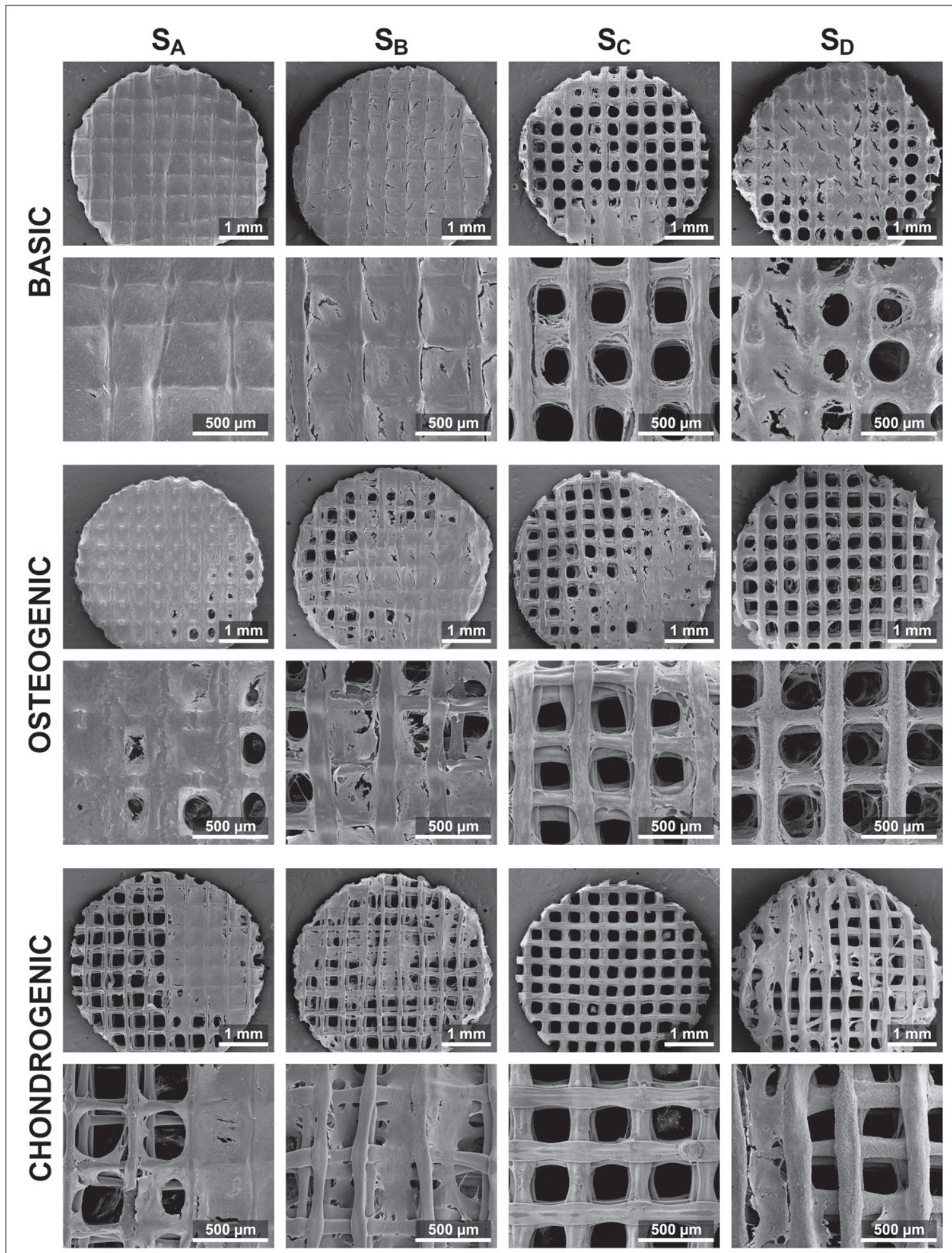

Figure 6. Scanning electron microscopy (SEM) images of the different scaffolds seeded with the low density of human mesenchymal stromal cells after a total of 9 days of culture (the last 7 days under basic or differentiation conditions).

$[22,23]$. Despite these advantages, wet-spinning still presents a few challenges to be solved. For example, when compared to 3D fibrous structures obtained by electrospinning, the additive manufactured wet-spun scaffolds present a larger pore size and fiber diameter. This results, in one hand, in better cell infiltration but, on the other hand, in less cell-material interactions.
Moreover, wet-spinning requires the dissolution of the polymer and relies on the potential need of post-processing to eliminate the residual solvents, the wet-spun structures present lower mechanical performance when compared to the FDM scaffolds, and usually there are morphological differences between the designed virtual model and the final 


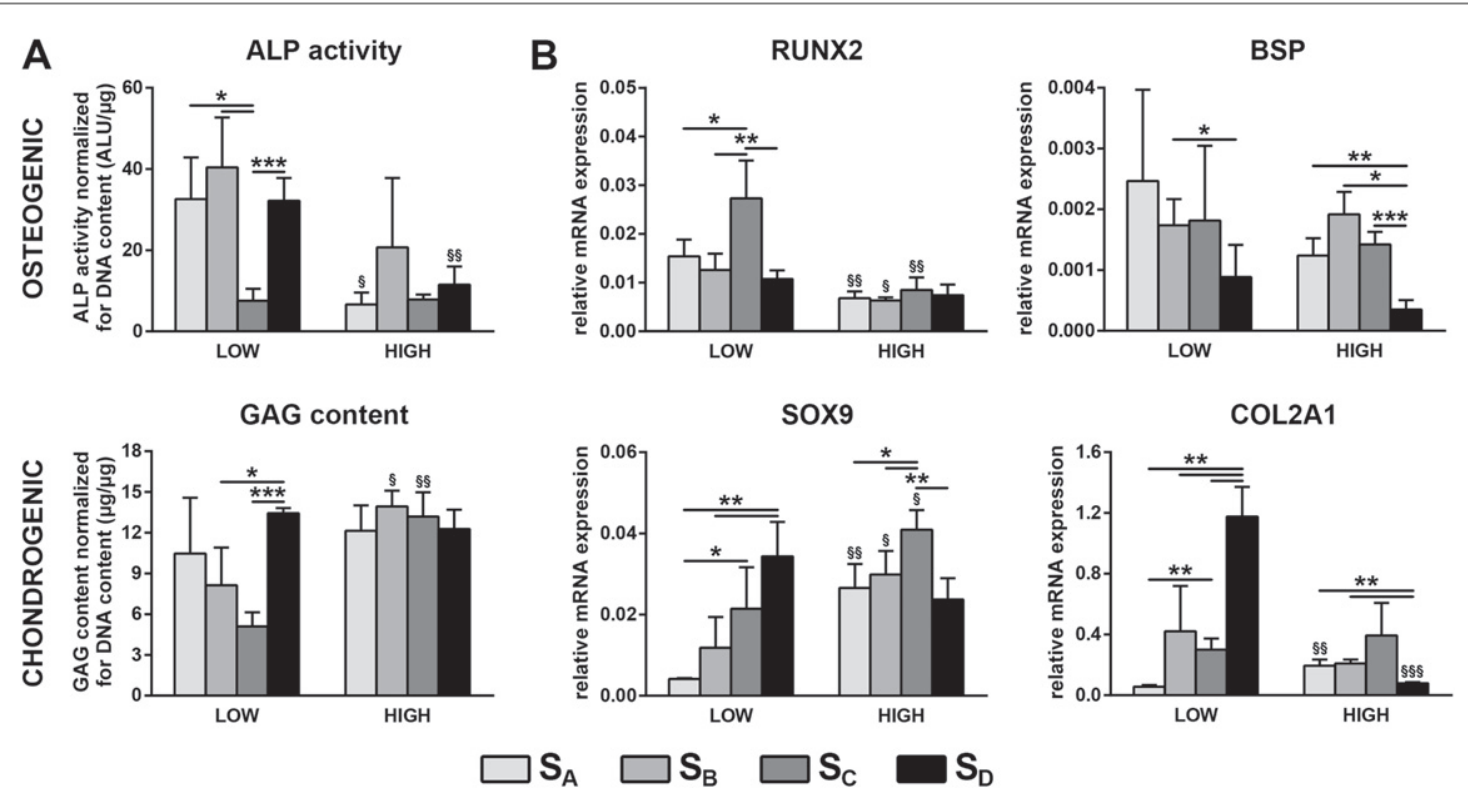

Figure 7. Activity of the human mesenchymal stromal cells (hMSCs) after a total of 9 days of culture (the last 7 days under basic or differentiation conditions), in the different scaffolds, initially seeded at different densities (25 000 and 125000 cells/scaffold, referred to as low and high cell seeding density, respectively). (A) Alkaline-phosphatase (ALP) activity and glycosaminoglycans (GAGs) content; (B) expression of osteogenic and chondrogenic-related genes (normalized for the B2M gene expression) $(n=3-6)$.

Statistically significant differences are marked with ${ }^{*}(p<0.05),{ }^{* *}(p<0.01)$ or ${ }^{* * *}(p<0.001)$ when comparing different topographies seeded with the same cell density and ${ }^{\S}(p<0.05),{ }^{\$ \S}(p<0.01)$ or ${ }^{\$ \$ \$}(p<0.001)$ when comparing the same topography seeded with the two different cell densities.

structure [26]. The geometry and the surface roughness of the scaffolds obtained by AM wet-spinning may be better controlled after a thorough study of all the possible combinations of the several parameters involved. As an example, the scaffolds geometry is strongly dependent on the polymer fibers' final morphology; in turn, the fibers' morphology is dependent on the plotting procedure and on the drying of the fibers. Their diameter can be controlled by changing the needle diameter, but a robust study must be performed in order to establish correlations between the needle internal diameter and the fiber shrinkage for each possible combination of parameters.

The use of physical cues to instruct cellular behavior has been raising considerable attention due to the advantages that it represents when compared to the use of (bio)chemical stimuli alone [3], as previously discussed. The great majority of related studies with hMSCs have been performed in 2D substrates [5-10], where a specific surface feature can be easily obtained, when compared to the fabrication of porous $3 \mathrm{D}$ constructs with a tailored surface topography [3, 12]. We successfully fabricated 3D PEOT/PBT scaffolds with different fibers roughness values (from $\approx 0.07$ to $1.95 \mu \mathrm{m}$ ) in one single step, and performed a preliminary assessment of the impact of surface roughness on hMSCs activity. In general, cells were able to proliferate, produce endogenous ECM, and differentiate in the developed 3D PEOT/PBT scaffolds, although significant differences were observed when low or high seeding densities were used.
Regarding cell proliferation, the higher proliferation rates observed for the lower cell density were most likely related to the higher amount of space that these cells had available to colonize the scaffold, as compared to the higher cell seeding density, which may have rapidly led to cell contact-inhibition.

Our focus was to obtain 3D fibrous scaffolds with different surface roughness values, which is mainly dictated by the solvent/non-solvent combination. When this combination changes, all other AM wet-spinning parameters have to be re-adjusted, which ultimately impacts the structural and geometrical characteristics of the final structure. Although we have tried to keep the scaffold pore network as similar as possible between scaffolds types, different geometrical features could be observed, such as $d_{\mathrm{z}}$ or fiber diameter. These might also have influenced the cellular behavior, in terms of cell-tocell contact and cell dimensionality, which have been reported to influence hMSCs activity [52, 54, 55]. Cells colonized the scaffold pores predominantly in a radial way, which is in accordance with previous studies on hMSCs space-filling growth in 3D porous scaffolds [56]. At a later stage, a slightly different behavior could be observed for the chondrogenic culture conditions, namely some cell clustering [57] within the scaffolds' pores and on top of the fibers. However, as we did not assess the influence of each geometrical characteristic individually, no direct correlations can be established between the cellular behavior observed and the scaffolds' pore network. 
Based on previous studies regarding the early impact of surface features in cellular behavior $[5,8,58]$, and due to the fact that at later stages cells start to be embedded in their own ECM, we have limited the in vitro studies to the referred nine days of culture. As recent studies indicate [10, 59], the propensity for differentiation that hMSCs exhibit when exposed to physical stimuli may cease if the exposure to the stimuli also ceases, and this might have also happened in this study when hMSCs started being embedded within the endogenous ECM. Using the high cell seeding density, chosen based on our previous data [60], we observed that the scaffolds got populated very quickly; hMSCs created a layer that partially covered the top fibers, and no remarkable differences could be observed in terms of hMSCs activity between topographies. Figure S2 in supplementary information may help to illustrate this phenomenon, where it can be observed that the ECM deposited on top of the fibers may mask or dilute the impact of the surface topography on the cells. In light of this, the study with a lower cell density interestingly unveiled the impact of surface roughness and/or topography on hMSCs behavior that was not possible to observe on the scaffolds seeded with the high cell density. In fact, the percentage of cells still in direct contact with the fibers surface, relatively to those embedded in the endogenous ECM, was higher for the low cell density, thus implying a higher exposure to the topographical stimuli.

Under osteogenic culture conditions, hMSCs exhibited a distinctive behavior on surface roughness values lower than $S_{C}$, presenting a slightly different morphology and a shift on the temporal profile of ALP production and RUNX2 expression [61], in comparison with the other scaffold types. The different morphology adopted by the hMSCs on the $S_{\mathrm{C}}$ scaffolds may have been influenced by the topography. It is well described in the literature that the morphology adopted by hMSCs when in contact with specific surface features influences their growth and/or differentiation [7, 58, 62, 63]. Cells contacted with different surface roughness profiles (supplementary information figure S1B), which might have influenced the different way that hMSCs attached to the surface of $S_{\mathrm{C}}$ scaffolds, leading to a cytoskeleton re-organization that resulted on the observed 'spindle-like' shape and, consequently, on their different behavior.

Other studies analyzed the influence of 3D scaffolds surface roughness and topography on the osteogenic differentiation of hMSCs [3, 12], although the use of different parameters make it difficult to establish a direct comparison with our study. The PCL FDM 3D scaffolds ( $5 \mathrm{~mm}$ diameter; $2 \mathrm{~mm}$ height) with surface roughened fibers by solvent-etching reported by Kumar et al [3] fall in the roughness range of our study (non-etched: $R_{\mathrm{a}} \approx 0.21 \mu \mathrm{m}$; etched: $\left.R_{\mathrm{a}} \approx 1.06 \mu \mathrm{m}\right)$. Differently from what we found, the roughest etched scaffolds induced hMSCs osteogenic differentiation, proven by calcified tissue and osteocalcin (OCN) secretion after 2 months (62 days) of culture. However, for earlier time-points (7 and 21 days), which are closer to the latest time-point of our study (9 days), no differences on cellular activity could be observed between scaffold types, even if they used a cell seeding density (5000 cells/scaffold) lower than the one used in our study. Mata et al [12] used 3D PDMS scaffolds and cultured the hMSCs up to 9 days on smooth and texturized surfaces (posts with $10 \mu \mathrm{m}$ diameter and $10 \mu \mathrm{m}$ height, separated by $10 \mu \mathrm{m}$ ). While texturized 3D scaffolds presented higher ALP mRNA expression by hMSCs, OCN mRNA expression was comparable for both types of scaffolds.

Regarding the culture under chondrogenic conditions, hMSCs seeded on the roughest $S_{\mathrm{D}}$ scaffolds were the ones that presented higher GAG production and concomitant higher mRNA expression of SOX9 and COL2A1. This might be partially related to the higher spatial proximity of the hMSCs cultured in these scaffolds, promoted by both the lower porosity and topographical features of the $S_{\mathrm{D}}$ scaffolds.

The preliminary assessment of the impact of using different cell seeding densities on these scaffolds indicates that this is a quite relevant parameter that should further be explored in more detail. The range of surface roughness values obtained in this study $(\approx 0.07-1.95 \mu \mathrm{m})$ could be further expanded in future studies to better investigate their effect on cellular activity. Our study supports that the physical cues presented on the surface of 3D scaffolds can play an important role in hMSCs behavior, but strengthens the premise that a defined balance needs to be established with all other parameters involved, like the cell seeding density, to obtain a proper growth and maturation of a specific type of tissue. In this respect, future studies should also aim at dissecting the net role of these interfacial properties when cellular multilayers are formed during tissue maturation.

\section{Conclusions}

This study presents the use of AM combined with wet-spinning for the fabrication of PEOT/PBT scaffolds with a good control over scaffold macro- and micro-architecture. Furthermore, we report that the methodology allows the production of $3 \mathrm{D}$ scaffolds whose polymer fibers have a tailored surface topography resultant from the process itself, and thus in a single-step without recurring to any kind of post-processing. The PEOT/PBT 3D scaffolds presented a highly porous morphology, and polymer fiber dimensions that fell in the range between FDM and electrospun porous structures. The in vitro assays performed using hMSCs showed that cells were able to adhere, proliferate and produce ECM in the developed scaffolds. The impact of the surface roughness on the 
osteogenic and chondrogenic fate-commitment of hMSCs was also assessed, showing that these were able to differentiate in both lineages, but the impact of surface topography was highly dependent on the initial cell density. This suggests that, on this type of scaffolds, the fine-tuning of surface roughness, topography, and cell seeding density is essential for guiding hMSCs differentiation along specific lineages.

\section{Acknowledgments}

Some of the materials used in this work were provided by the Texas A\&M Health Science Center College of Medicine Institute for Regenerative Medicine at Scott \& White through a grant from NCRR of the NIH (Grant \#P40RR017447). This work was financed by the European Regional Development Fund (ERDF) through the Programa Operacional Factores de Competitividade-COMPETE, and by Portuguese funds through FCT-Fundação para a Ciência e a Tecnologia in the framework of SC Neves doctoral grant SFRH/BD/76995/2011, the research position of CC Barrias (FCT Investigator, IF2013), the research grant PEst-C/SAU/LA0002/2011, and co-financed by North Portugal Regional Operational Programme (ON.2-O Novo Norte) in the framework of the project SAESCTN-PIIC\&DT/1/2011, under the National Strategic Reference Framework (NSRF). This project/research has also been made possible with the support of the Dutch Province of Limburg.

\section{References}

[1] Melchels F P W, Domingos M A N, Klein T J, Malda J, Bartolo P J and Hutmacher D W 2012 Additive manufacturing of tissues and organs Prog. Polym. Sci. 37 1079-104

[2] Mota C, Puppi D, Chiellini F and Chiellini E 2015 Additive manufacturing techniques for the production of tissue engineering constructs J. Tissue Eng. Regen. Med. 9 174-90

[3] Kumar G, Waters M S, Farooque T M, Young M F and Simon C G 2012 Freeform fabricated scaffolds with roughened struts that enhance both stem cell proliferation and differentiation by controlling cell shape Biomaterials 33 4022-30

[4] Dimarino A M, Caplan A I and Bonfield T L 2013 Mesenchymal stem cells in tissue repair Front. Immunol. 4201

[5] Khang D, Choi J, Im Y-M, Kim Y-J, Jang J-H, Kang S S, Nam T-H, Song J and Park J-W 2012 Role of subnano-, nanoand submicron-surface features on osteoblast differentiation of bone marrow mesenchymal stem cells Biomaterials 33 5997-6007

[6] Wu Y-N, Law J B K, He A Y, Low H Y, Hui J H P, Lim C T, Yang Z and Lee E H 2014 Substrate topography determines the fate of chondrogenesis from human mesenchymal stem cells resulting in specific cartilage phenotype formation Nanomedicine Nanotechnol. Biol. Med. 10 1507-16

[7] Kolind K, Leong K W, Besenbacher F and Foss M 2012 Guidance of stem cell fate on 2D patterned surfaces Biomaterials 33 6626-33

[8] Fiedler J, Ozdemir B, Bartholomä J, Plettl A, Brenner R E and Ziemann P 2013 The effect of substrate surface nanotopography on the behavior of multipotnent mesenchymal stromal cells and osteoblasts Biomaterials 34 8851-9
[9] Watari S, Hayashi K, Wood J A, Russell P, Nealey P F, Murphy C J and Genetos D C 2012 Modulation of osteogenic differentiation in hMSCs cells by submicron topographicallypatterned ridges and grooves Biomaterials 33 128-36

[10] Abagnale Get al 2015 Surface topography enhances differentiation of mesenchymal stem cells towards osteogenic and adipogenic lineages Biomaterials 61 316-26

[11] Baker B A, Pine P S, Chatterjee K, Kumar G, Lin N J, McDaniel J H, Salit M L and Simon C G 2014 Ontology analysis of global gene expression differences of human bone marrow stromal cells cultured on $3 \mathrm{D}$ scaffolds or $2 \mathrm{D}$ films Biomaterials 35 6716-26

[12] Mata A, Kim E J, Boehm C A, Fleischman A J, Muschler G F and Roy S 2009 A three-dimensional scaffold with precise micro-architecture and surface micro-textures Biomaterials 30 4610-7

[13] Giannitelli S M, Accoto D, Trombetta M and Rainer A 2014 Current trends in the design of scaffolds for computer-aided tissue engineering Acta Biomater. 10 580-94

[14] Moroni L, de Wijn J R and van Blitterswijk C A 2006 3D fiberdeposited scaffolds for tissue engineering: Influence of pores geometry and architecture on dynamic mechanical properties Biomaterials 27 974-85

[15] Moroni L, Curti M, Welti M, Korom S, Weder W, de Wijn J R and van Blitterswijk C A 2007 Anatomical 3D fiberdeposited scaffolds for tissue engineering: designing a neotrachea Tissue Eng. 13 2483-93

[16] Neves S C, Moreira Teixeira L S, Moroni L, Reis R L, Van Blitterswijk C A, Alves N M, Karperien M and Mano J F 2011 Chitosan/poly( $\varepsilon$-caprolactone) blend scaffolds for cartilage repair Biomaterials 32 1068-79

[17] Leonor I B, Rodrigues M T, Gomes M E and Reis R L 2011 In situ functionalization of wet-spun fibre meshes for bone tissue engineering J. Tissue Eng. Regen. Med. 5 104-11

[18] Diban N, Haimi S, Bolhuis-Versteeg L, Teixeira S, Miettinen S, Poot A, Grijpma D and Stamatialis D 2013 Hollow fibers of poly(lactide-co-glycolide) and poly( $\varepsilon$-caprolactone) blends for vascular tissue engineering applications Acta Biomater. 9 6450-8

[19] Mota C, Puppi D, Dinucci D, Gazzarri M and Chiellini F 2013 Additive manufacturing of star poly(-caprolactone) wet-spun scaffolds for bone tissue engineering applications J. Bioact. Compat. Polym. 28 320-40

[20] Mota C, Wang S, Puppi D, Gazzarri M, Migone C, Chiellini F, Chen $\mathrm{G}$ and Chiellini E 2014 Additive manufacturing of poly [(R)-3-hydroxybutyrate-co-(R)-3-hydroxyhexanoate] scaffolds for engineered bone development J. Tissue Eng. Regen. Med.n/a-n/a (doi:10.1002/term.1897)

[21] Lin H-Y, Peng C-W and Wu W-W 2014 Fibrous hydrogel scaffolds with cells embedded in the fibers as a potential tissue scaffold for skin repair J. Mater. Sci. Mater. Med. 25 259-69

[22] Puppi D, Dinucci D, Bartoli C, Mota C, Migone C, Dini F, Barsotti G, Carlucci F and Chiellini F 2011 Development of 3D wet-spun polymeric scaffolds loaded with antimicrobial agents for bone engineering J. Bioact. Compat. Polym. 26 478-92

[23] Puppi D, Piras A M, Pirosa A, Sandreschi S and Chiellini F 2016 Levofloxacin-loaded star poly(e-caprolactone) scaffolds by additive manufacturing J. Mater. Sci. Mater. Med. 27 1-11

[24] Puppi D, Zhang X, Yang L, Chiellini F, Sun X and Chiellini E 2014 Nano/microfibrous polymeric constructs loaded with bioactive agents and designed for tissue engineering applications: a review J. Biomed. Mater. Res. B 102 1562-79

[25] Giannitelli S M, Mozetic P, Trombetta M and Rainer A 2015 Combined additive manufacturing approaches in tissue engineering Acta Biomater. 24 1-11

[26] Puppi D, Mota C, Gazzarri M, Dinucci D, Gloria A Myrzabekova M, Ambrosio L and Chiellini F 2012 Additive manufacturing of wet-spun polymeric scaffolds for bone tissue engineering Biomed. Microdevices 14 1115-27

[27] Groll J et al 2016 Biofabrication: reappraising the definition in an evolving field Biofabrication 1-6 013001

[28] Moroni L, de Wijn J R and van Blitterswijk C A 2005 Threedimensional fiber-deposited PEOT/PBT copolymer scaffolds 
for tissue engineering: influence of porosity, molecular network mesh size, and swelling in aqueous media on dynamic mechanical properties J. Biomed. Mater. Res. A 75A 957-65

[29] Deschamps A A, Van Apeldoorn A A, Hayen H, De Bruijn J D, Karst U, Grijpma D W and Feijen J 2004 In vivo and in vitro degradation of poly(ether ester) block copolymers based on poly(ethylene glycol) and poly(butylene terephthalate) Biomaterials 25 247-58

[30] Bezemer J, Grijpma D, Dijkstra P, van Blitterswijk C and Feijen J 1999 A controlled release system for proteins based on poly(ether ester) block-copolymers: polymer network characterization J. Control. Release 62 393-405

[31] van Dijkhuizen-Radersma R, Péters F L A M A, Stienstra N A, Grijpma D W, Feijen J, de Groot K and Bezemer J M 2002 Control of vitamin B12 release from poly(ethylene glycol)/ poly(butylene terephthalate) multiblock copolymers Biomaterials 23 1527-36

[32] Bartha L et al 2013 A clinical feasibility study to evaluate the safety and efficacy of PEOT/PBT implants for human donor site filling during mosaicplasty Eur. J. Orthop. Surg. Traumatol. 23 81-91

[33] Woodfield T B F, Malda J, de Wijn J, Péters F, Riesle J and van Blitterswijk C A 2004 Design of porous scaffolds for cartilage tissue engineering using a three-dimensional fiberdeposition technique Biomaterials 25 4149-61

[34] Landers R, Pfister A, Hübner U, John H, Schmelzeisen R and Mülhaupt R 2002 Fabrication of soft tissue engineering scaffolds by means of rapid prototyping techniques J. Mater. Sci. 37 3107-16

[35] Rasband W S 1997-2015 ImageJ (Bethesda, MA: US National Institutes of Health)

[36] Farndale R W, Buttle D J and Barrett A J 1986 Improved quantitation and discrimination of sulphated glycosaminoglycans by use of dimethylmethylene blue Biochim. Biophys. Acta 883 173-7

[37] Dini F et al 2015 Tailored star poly ( $\varepsilon$-caprolactone) wet-spun scaffolds for in vivo regeneration of long bone critical size defects J. Bioact. Compat. Polym. 31 15-30

[38] Peng N, Widjojo N, Sukitpaneenit P, Teoh M M, Lipscomb G G, Chung T-S and Lai J-Y 2012 Evolution of polymeric hollow fibers as sustainable technologies: past, present, and future Prog. Polym. Sci. 37 1401-24

[39] Mulder M 1996 Basic Principles of Membrane Technology (Berlin: Springer)

[40] Strathmann H, Scheible P and Baker R W 1971 A rationale for the preparation of Loeb-Sourirajan-type cellulose acetate membranes J. Appl. Polym. Sci. 15 811-28

[41] Rodrigues A I, Oliveira M B, Mano J F, Gomes M E, Reis R L and Leonor I B 2015 Combinatorial effect of silicon and calcium release from starch-based scaffolds on osteogenic differentiation of human adipose stem cells ACS Biomater. Sci. Eng. $1760-70$

[42] Papenburg B J, Vogelaar L, Bolhuis-Versteeg L A M, Lammertink R G H, Stamatialis D and Wessling M 2007 Onestep fabrication of porous micropatterned scaffolds to control cell behavior Biomaterials 28 1998-2009

[43] Radjabian M, Koll J, Buhr K, Handge U A and Abetz V 2013 Hollow fiber spinning of block copolymers: influence of spinning conditions on morphological properties Polymer 54 1803-12

[44] Sukitpaneenit P and Chung T S 2009 Molecular elucidation of morphology and mechanical properties of PVDF hollow fiber membranes from aspects of phase inversion, crystallization and rheology J. Memb. Sci. 340 192-205

[45] Vehviläinen M, Kamppuri T, Rom M, Janicki J, Ciechańska D, Grönqvist S, Siika-Aho M, Elg Christoffersson K and Nousiainen P 2008 Effect of wet spinning parameters on the properties of novel cellulosic fibres Cellulose 15 671-80

[46] Cai J, Zhang L, Zhou J, Qi H, Chen H, Kondo T, Chen X and Chu B 2007 Multifilament fibers based on dissolution of cellulose in $\mathrm{NaOH} /$ urea aqueous solution: structure and properties Adv. Mater. 19 821-5

[47] Um I C, Kweon H Y, Lee K G, Ihm D W, Lee J-H and Park Y H 2004 Wet spinning of silk polymer: I. Effect of coagulation conditions on the morphological feature of filament Int. J. Biol. Macromol.34 89-105

[48] Lee K H, Baek D H, Ki C S and Park Y H 2007 Preparation and characterization of wet spun silk fibroin/poly(vinyl alcohol) blend filaments Int. J. Biol. Macromol. 41 168-72

[49] Dong X-G, Wang C-G, Bai Y-J and Cao W-W 2007 Effect of DMSO/H2O coagulation bath on the structure and property of polyacrylonitrile fibers during wet-spinning J. Appl. Polym. Sci. 105 1221-7

[50] Park T G, Cohen S and Langer R 1992 Poly(L-lactic acid)/ pluronic blends: characterization of phase separation behavior, degradation, and morphology and use as protein-releasing matrixes Macromolecules 25 116-22

[51] Hendriks J A A, Moroni L, Riesle J, de Wijn J R and van Blitterswijk C A 2013 The effect of scaffold-cell entrapment capacity and physico-chemical properties on cartilage regeneration Biomaterials 34 4259-65

[52] Moroni L, Licht R, de Boer J, de Wijn J R and van Blitterswijk C A 2006 Fiber diameter and texture of electrospun PEOT/PBT scaffolds influence human mesenchymal stem cell proliferation and morphology, and the release of incorporated compounds Biomaterials 27 4911-22

[53] Karageorgiou V and Kaplan D 2005 Porosity of 3D biomaterial scaffolds and osteogenesis Biomaterials 26 5474-91

[54] Cardwell R D, Dahlgren L A and Goldstein A S 2014 Electrospun fibre diameter, not alignment, affects mesenchymal stem cell differentiation into the tendon/ ligament lineage J. Tissue Eng. Regen. Med. 8937-45

[55] Farooque T M, Camp C H, Tison C K, Kumar G, Parekh S H and Simon C G 2014 Measuring stem cell dimensionality in tissue scaffolds Biomaterials 35 2558-67

[56] Herklotz M, Prewitz M C, Bidan C M, Dunlop J W C, Fratzl P and Werner C 2015 Availability of extracellular matrix biopolymers and differentiation state of human mesenchymal stem cells determine tissue-like growth in vitro Biomaterials 60 121-9

[57] Cai R, Nakamoto T, Kawazoe N and Chen G 2015 Influence of stepwise chondrogenesis-mimicking $3 \mathrm{D}$ extracellular matrix on chondrogenic differentiation of mesenchymal stem cells Biomaterials 52 199-207

[58] Treiser M D, Yang E H, Gordonov S, Cohen D M, Androulakis I P, Kohn J, Chen C S and Moghe P V 2010 Cytoskeleton-based forecasting of stem cell lineage fates Proc. Natl Acad. Sci. USA 107 610-5

[59] Schellenberg A et al 2014 Matrix elasticity, replicative senescence and DNA methylation patterns of mesenchymal stem cells Biomaterials 35 6351-8

[60] Leferink A M, Hendrikson W J, Rouwkema J, Karperien M, van Blitterswijk C A and Moroni L 2013 Increased cell seeding efficiency in bioplotted three-dimensional PEOT/PBT scaffolds J. Tissue Eng. Regen. Med. (http://dx.doi.org/ 10.1002/term.1842) (doi:10.1002/term.1842)

[61] Liu T M and Lee E H 2013 Transcriptional regulatory cascades in Runx2-dependent bone development Tissue Eng. B 19 254-63

[62] Kumar G, Tison C K, Chatterjee K, Pine P S, McDaniel J H, Salit M L, Young M F and Simon C G 2011 The determination of stem cell fate by $3 \mathrm{D}$ scaffold structures through the control of cell shape Biomaterials 32 9188-96

[63] Mathieu P S and Loboa E G 2012 Cytoskeletal and focal adhesion influences on mesenchymal stem cell shape, mechanical properties, and differentiation down osteogenic, adipogenic, and chondrogenic pathways Tissue Eng. B 18 436-44 